\title{
A simple approach to water and plankton sampling for water microbiological and physicochemical characterizations at various depths in aquatic ecosystems
}

\author{
Fatthy Mohamed Morsy* \\ Botany Department, Faculty of Science, Assiut University, Assiut, Egypt
}

Received 2 June 2010; Accepted 14 September 2010

\begin{abstract}
Water microbiological and physicochemical characterizations at various depths of aquatic ecosystems are basic requirements in several fields of research. A chief difficulty in hydrobiology, limnology, biological oceanography and water environmental microbiology is that of taking accurate field collections that are representative of the natural environment and population at various depths of aquatic ecosystems. Gathering water/plankton samples in a level just below the surface of the water body upon rising in columns from various depths due to hydrostatic pressure variations provided a simple approach for water and plankton sampling. Based on this approach, several forms of simple devices for water and plankton sampling were developed for water microbiological and physicochemical characterizations at various depths of aquatic ecosystems. The described approach showed less sampling errors in comparison to Van Dorn bottle and was comparable to water pumping but requires no external source of power. The described samplers are inexpensive and can be self constructed.
\end{abstract}

Key words: Alga / aquatic ecosystem / cyanobacterium / phytoplankton / river / sampler / water

\section{Introduction}

A major problem of studies on the water microflora and microfauna in general is the need for accurate estimates and sampling of the standing crop at various depths in aquatic ecosystems. Phytoplankton, bacterioplankton, and microscopic zooplankton such as protozoan are some of the water microorganisms. Plankton in general can be collected by towed plankton nets and plankton traps (Pierce, 1937; Slack, 1955; Clarke, 1964; Longhurst et al., 1966; Heron, 1982; Kimmerer, 1984; O'Hara, 1984; Wiebe and Benfield, 2003). Quantitative and qualitative phyto- and zooplankton harvesting by nets and plankton traps can involve many technical difficulties and errors (Hopkins, 1963; Tuel and Knauer, 1982; Hernroth, 1987; Boney, 1989; Hays, 1994; John et al., 2002).

Many water microorganisms cannot be collected by nets but require water sampling from various depths to be characterized in laboratory. Various equipments have been developed for obtaining water samples from various depths of water bodies for further laboratory microflora and microfauna characterizations (Lund and Talling,

\footnotetext{
*Corresponding author: fmorsy@aun.edu.eg
}

1957; Van Dorn, 1957; Nicholls, 1979; Sutherland et al., 1992; Sauter et al., 2005; Seuront and Menu, 2006; Ahn et al., 2008). However, such devices often have difficulties in their operation and control in the field. They are limited in sampling volume and have restrictions in maximum depth to which they can be used. The pumping approach has been effectively applied over decades for water and plankton sampling; however, it often requires a means of lifting the water, without having the sample pass through the pumping mechanism for reducing the risk of shearing phytoplankton colonies.

Towed video microscopy was used to unobtrusively determine distributions of oceanic plankton over a continuum of scales from microns to hundreds of meters (Davis et al., 1992a, 1992b, 1996). However, samples on hand are still required for laboratory manipulations and characterization of undetectable microorganisms by the video plankton recorder (VPR). In addition, it is not always possible to identify organisms imaged with VPR to the species level (Benfield et al., 1996). The work undertaken here describes a simple approach and the construction details and field application of several forms of simple devices for water and plankton sampling for water microbiological and physicochemical characterizations at various depths of aquatic ecosystems. 
A

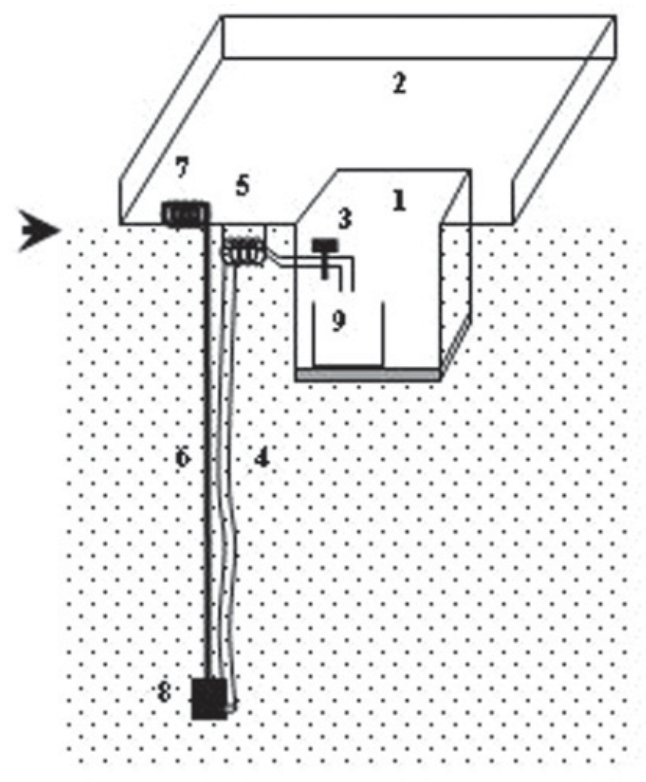

B

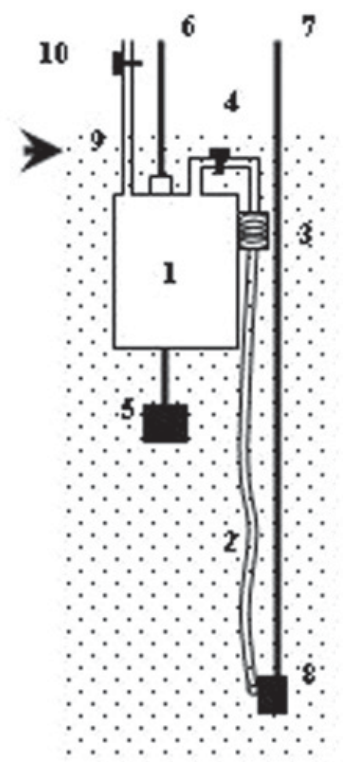

Fig. 1. Diagrammatic view of two forms of the water/plankton samplers showing their construction details. The sampler (A) consists of a metallic sampler chamber (1), rubber edges (2), tap (3), rubber tube (4), rubber tube coil (5), rope (6), rope coil (7), metal weight (8) and sample bottle (9). Operation and sampling technique of the device are described in the text. The sampler (B) consists of a sample collection bottle (1) to which a rubber tube (2) extending from a tube coil (3) was connected to a tape (4) at the top of the bottle. The bottle with attached metal weight (5) was immersed just below the water surface and knotted to a float (boat bumper) by a rope (6). The tube was immersed in the water body with its inlet bound to the end of a rope (7) and a metal weight (8). The rope (7) of a desired length was led to the surface and knotted to a float. Another opening of the bottle was connected to a rubber tube (9) extending outside the water surface and its free opening is controlled by a tap (10). With the taps (4 and 10) opened, water continuously passed from the target depth through the rubber tube (2) and was collected in the sample collection bottle (1). The arrow heads refer to the surface of the water body.

\section{Material and methods}

\section{Construction details and operation of the water/plankton samplers}

The water/plankton sampler (Fig. 1A) consists of a metallic sampler chamber immersed just below the surface of the water body and supported by floating rubber edges. The sampler chamber contains a tap in a position just below the water surface and connected to a rubber tube. The free inlet of the tube was connected to the end of a rope where a metal weight was bound. With the tap closed, the rope of a desired length, the inlet of the rubber tube and the metal weight were immersed in the water body to the desired depth. With the tap opened, water continuously passed from the target depth through the rubber tube to the tap in the sampler chamber and collected in volumes as much as required. For collecting samples from a different depth, the tap was closed and the length of the rope was re-adjusted. Then the tap was opened and water samples equal to three times the tube volume were discarded after which the target sample was collected in volumes as much as required. Several forms of the tubing systems have been tested including compact multilevel tubes with several taps in the sampling collection chamber for each prescribed depth (diagrammatic view not shown).

Another form of the water/plankton sampler was developed (Fig. 1B). The sampler operates by using hydrostatic pressure to allow water flow from a desired depth to a collection bottle open to the atmosphere located just below the water surface. In this form of the device, water passes from the desired depth through a rubber tube and is collected in a sample bottle held under the water surface by just few centimeters.

For quantitative plankton collection from various depths of the aquatic ecosystem, the water sampling system described above was supplemented with a plankton filtration unit (Fig. 2). The tap of the water sampling system was connected to the inlet of the plankton filtration unit which consists of a plankton gathering bottle containing a small cone net connected to the outlet of the plankton gathering bottle. The cone net can be made from a variety of materials with different mesh sizes for filtering various plankton size classes. 


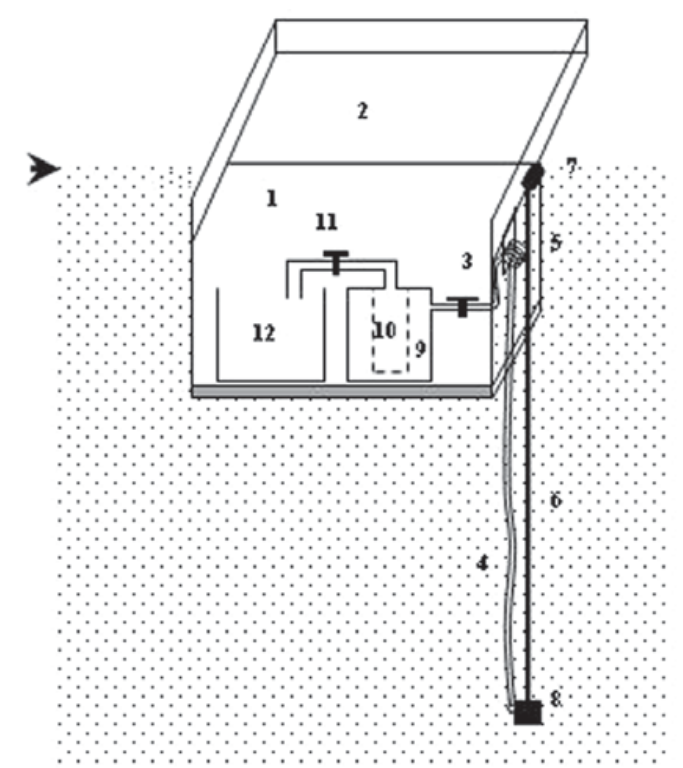

Fig. 2. Diagrammatic view of the plankton sampler showing its construction details. The device consists of a metallic sampler chamber (1), rubber edges (2), tap (3), rubber tube (4), rubber tube coil (5), rope (6), rope coil (7), metal weight (8), plankton gathering bottle (9), plankton filter (10), tap (11) and water gathering bottle (12). Operation and sampling technique of the device are described in the text. The arrow head refers to the water surface.

\section{Study sites}

Water and plankton sampling using the devices described in this study and a Van Dorn horizontal bottle for comparison was conducted in the Nile River at Assiut governorate (375 km south from Cairo, Egypt). Sampling was also conducted in El-Malah canal at Assiut governorate (map not shown). This canal is exposed to domestic sewage disposal and industrial effluent and has a high abundance of bloom forming cyanobacteria.

\section{Determination of chlorophyll a (chl a) and C-phycocyanin (C-PC)}

Chl $a$ was dark-extracted under cooling in $100 \%$ methanol for $24 \mathrm{~h}$, clarified by centrifugation under cooling $\left(4^{\circ} \mathrm{C}\right)$ at $7000 \times g$ for $15 \mathrm{~min}$ and quantified spectrophotometrically according to the equations of Holden (1976). C-PC was extracted as described by Sarada et al. (1999). Thylakoid membranes were precipitated from the crude extracts using 1\% streptomycin sulfate and the extracts were clarified by centrifugation under cooling $\left(4{ }^{\circ} \mathrm{C}\right)$ at $7000 \times g$ for $15 \mathrm{~min}$. The concentration of C-PC in the extracts was quantified spectrophotometrically according to the equations of Bennett and Bogorad (1973).

\section{Results}

A continuous water flow from the desired water depth was observed when gathering water samples at a level just below the surface. Based on this approach, several forms of simple devices for water/plankton sampling for water microbiological and physicochemical characterizations at various depths of aquatic ecosystems were developed. Several forms of these samplers with various sizes and construction materials were applicable. A fourth form for quantitative plankton collection was constructed by adding a plankton filtration unit in the inlet of the water collection bottle (Fig. 1B) which showed no significant differences in the plankton count/community in comparison with the device shown in Figure 2 (data not shown).

There is a keen interest in the aquatic sciences community to advance simple sampling methods that are helpful for making observations without disturbing the natural state of a sample. Vertical profiling of phytoplankton in the Nile River using the device (Fig. 1A) described in this study showed two zones of phytoplankton population. The upper zone (down to $3.5 \mathrm{~m}$ in depth) contained a high phytoplankton density as revealed by phytoplankton abundance (Fig. 3A) and chl $a$ content (Fig. 3B) profiles while the lower zone (down $3.5 \mathrm{~m}$ depth) contained a low density of phytoplankton. Such distinction between the two zones was not clear in case of Van Dorn bottle. In addition, the water samples collected by the sampler described in this study showed less variable phytoplankton abundance (Fig. 3A) and chl $a$ content (Fig. 3B), producing lower values of standard errors in comparison to Van Dorn bottle. Low values of standard deviation were also recorded for the measured physicochemical properties (Table 1) among replicate samples from the same site/depth collected using the samplers described in this study (Fig. 1) in comparison to Van Dorn bottle. These results indicate no disturbance of the plankton community occurred when using the devices described in this study for vertical profiling of an aquatic ecosystem possibly because the devices described in this study allow for repeat sampling at the same site/depth without raising the device. Thus, low values of standard deviation were observed in comparison to Van Dorn bottle which requires raising the whole bottle out of the water and immersing it again to collect replicate samples, which causes a disturbance in the plankton community.

Bloom forming cyanobacteria were observed in the El-Malah canal at Assiut governorate. The filamentous cyanobacterium Oscillatoria sp. was dominant in this canal (data not shown). Accordingly C-PC, a characteristic accessory photosynthetic pigment of cyanobacteria, can be used as an index of cyanobacterial abundance. The concentration profile of C-PC at 09:00, 12:00, 16:00 and 24:00 was conducted using the water sampler (form A) described in this study (Fig. 4A) and Van Dorn bottle (Fig. 4B) to compare the efficiency of both sampling methods in profiling the diel vertical migration of cyanobacteria. The C-PC profile observed by the water sampler described in this study (Fig. 4A) showed high cyanobacterial abundance close to the water surface of the canal at 09:00 while the C-PC profiles at 12:00, 16:00 and 24:00 showed a downward vertical movement pattern of cyanobacteria. Such vertical movement pattern was not 
A

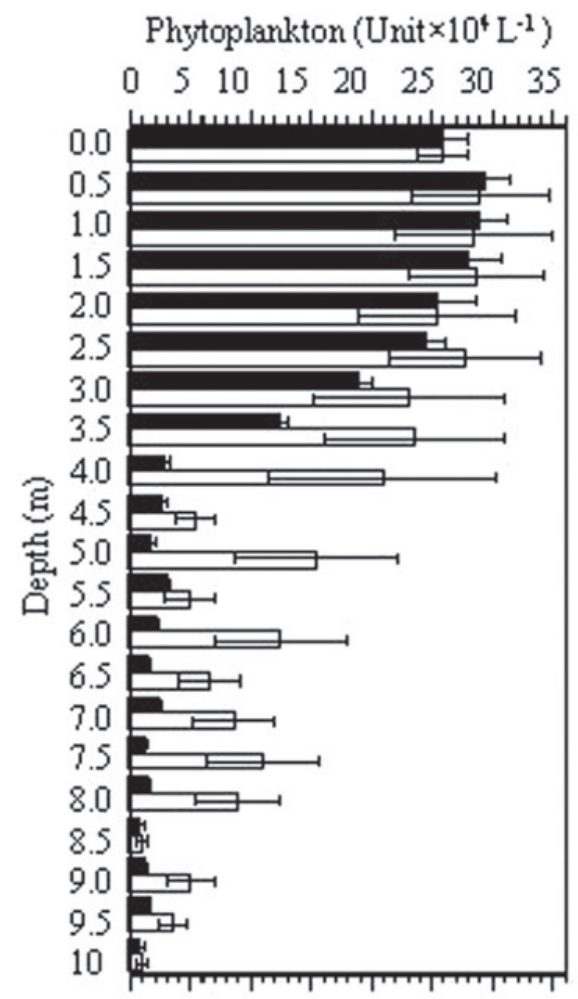

B

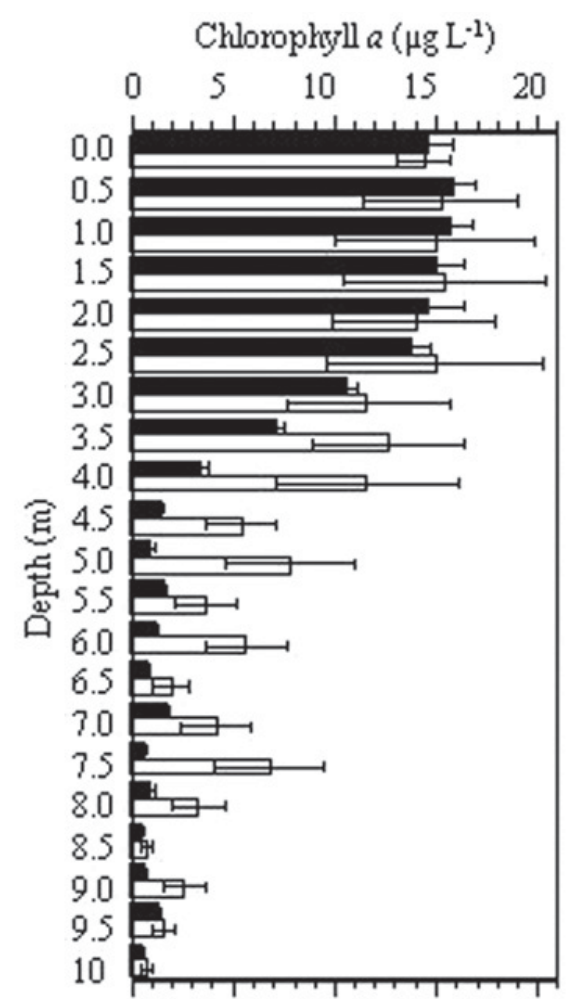

Fig. 3. Comparison of the phytoplankton vertical abundance and chl $a$ content between the water sampler described in this study and Van Dorn bottle. The vertical abundance of phytoplankton (panel A) and the vertical profile of chl $a$ (panel B) as a marker of phytoplankton abundance in the Nile River were conducted using the water sampler (form A) described in this study (black columns) and Van Dorn bottle (white columns). Sampling was carried out near midday in full sunshine. Mean values and standard error bars are of three replicates.

clear in case of Van Dorn bottle (Fig. 4B) probably because of the disturbance caused by repeat sampling.

\section{Discussion}

In spite of their wide application, towed plankton nets and plankton traps were developed to be used in open waters of large and deep water bodies (Burd and Thomson, 1993; Warner and Hays, 1994; Batten et al., 2003; Wiebe and Benfield, 2003). However, it is often necessary to take samples in special environments, shallow or densely vegetated, where the use of the conventional sampling devices presents many technical difficulties. The described approach in this study is very suitable for such environments, which are not well served by plankton nets. The various forms of devices described in this study might apply to the original definition of microscale, i.e., scales smaller than $1 \mathrm{~m}$ (Mackas et al., 1985; Seuront and Menu, 2006). In contrast, limitations of currently used traditional plankton samplers (e.g., nets) have precluded sampling at resolutions finer than $10 \mathrm{~m}$ horizontally or $5 \mathrm{~m}$ vertically (Davis et al., 1992b) which has resulted in a dearth of direct measurement of physical, chemical, and biological distributions on ecologically meaningful scales (Davis et al., 1992a; Donaghay et al., 1992; Kils, 1992; Schulze et al., 1992; Seuront and Menu, 2006). The water samplers described here also result in a considerable savings of time, thus allowing a greater number of samples to be collected. The continuous water flow allowed for a large volume of water to be easily sampled quantitatively from various depths of the water body. This is in contrast to most of the automated traditional water samplers that have been described in the literature which were based on lowering the man body of the sampler to the desired depth where it collects a fixed volume of water, which must be raised with the device. The original samplers described elsewhere were based on modified single or multilevel Kemmerer, Van Dorn, or Niskin samplers and designed to operate in a horizontal and/or vertical position to investigate microstructure in open water, stratified waters, and at the water-sediment interface (Lund, 1954; Walker, 1955; Van Dorn, 1957; Finucane and May, 1961; Gleason and Goff, 1963; Joeris, 1964; Summerfelt and Lewis, 1968; Culberson and Pytkowicz, 1970; Seuront and Menu, 2006). Those samplers were further replaced by smaller and more versatile multilevel glass bottle (Baker, 1970) and syringe (Broenkow, 1969; Clasby et al., 1972; Heaney, 1974; Blakar, 1979; Seymour et al., 2000) samplers. The technical difficulties of those previously described 
Table 1. Comparison of physicochemical characteristics of water samples collected using devices described in this study and water samples collected by Van Dorn bottle.

\begin{tabular}{|c|c|c|c|c|c|c|c|c|c|}
\hline \multirow[b]{3}{*}{ Parameters } & \multicolumn{9}{|c|}{ Depth (m) } \\
\hline & \multicolumn{3}{|c|}{1} & \multicolumn{3}{|c|}{5} & \multicolumn{3}{|c|}{10} \\
\hline & $\begin{array}{c}\text { Device } \\
\text { form }(\mathrm{A})\end{array}$ & $\begin{array}{l}\text { Device } \\
\text { form }(\mathrm{B})\end{array}$ & Van Dorn & $\begin{array}{c}\text { Device } \\
\text { form }(\mathrm{A})\end{array}$ & $\begin{array}{c}\text { Device } \\
\text { form }(\mathrm{B})\end{array}$ & Van Dorn & $\begin{array}{c}\text { Device } \\
\text { form }(\mathrm{A})\end{array}$ & $\begin{array}{c}\text { Device } \\
\text { form (B) }\end{array}$ & Van Dorn \\
\hline$\overline{\mathrm{pH}}$ & $7.85 \pm 0.12$ & $7.85 \pm 0.15$ & $7.7 \pm 0.23$ & $7.2 \pm 0.1$ & $7.05 \pm 0.12$ & $7.4 \pm 0.6$ & $6.15 \pm 0.2$ & $6.1 \pm 0.16$ & $6.6 \pm 1.3$ \\
\hline $\begin{array}{l}\text { Dissolved oxygen } \\
\left(\mathrm{mg} \cdot \mathrm{L}^{-1}\right)\end{array}$ & $12.7 \pm 1.95$ & $13.6 \pm 2$ & $14.5 \pm 4.7$ & $9 \pm 1.4$ & $8.5 \pm 1.7$ & $10 \pm 4$ & $5.5 \pm 1$ & $5 \pm 1.1$ & $6.5 \pm 3.5$ \\
\hline $\begin{array}{l}\text { Electric conductivity } \\
\left(\mu \mathrm{S} . \mathrm{cm}^{-1}\right)\end{array}$ & $189 \pm 8$ & $194 \pm 9$ & $176 \pm 28$ & $202 \pm 12$ & $210 \pm 11.6$ & $175.5 \pm 35$ & $379.5 \pm 36.5$ & $389.5 \pm 34$ & $322.5 \pm 75$ \\
\hline TSS $\left(\mathrm{mg} \cdot \mathrm{L}^{-1}\right)^{\mathrm{a}}$ & $121 \pm 5.1$ & $124 \pm 5.8$ & $112.9 \pm 17.9$ & $129.3 \pm 7.7$ & $134.4 \pm 7$ & $112.4 \pm 22.4$ & $243.1 \pm 23.3$ & $249 \pm 21.8$ & $206.6 \pm 48$ \\
\hline
\end{tabular}

Samples were collected at 1, 5 and $10 \mathrm{~m}$ depth of the Nile River using devices described in this study and Van Dorn bottle for comparison.

aTSS, total suspended solids.

Mean values and standard deviations are of three replicates.

A

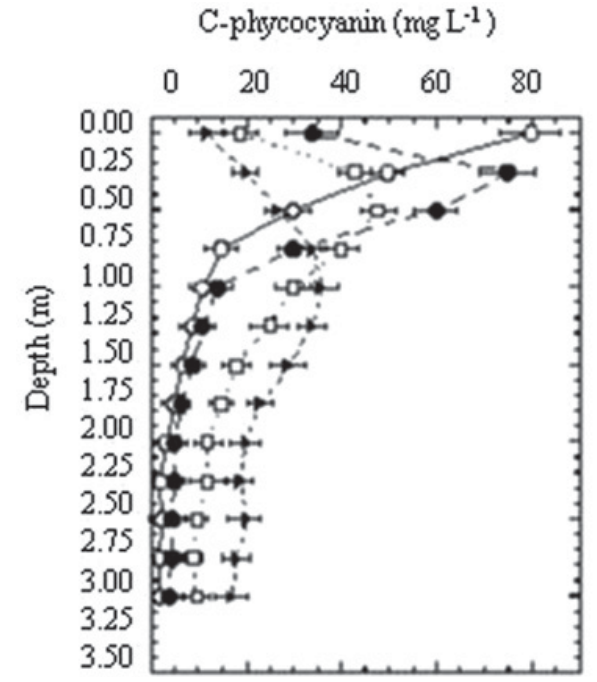

B

C-phycocyanin (mg L-1 $)$

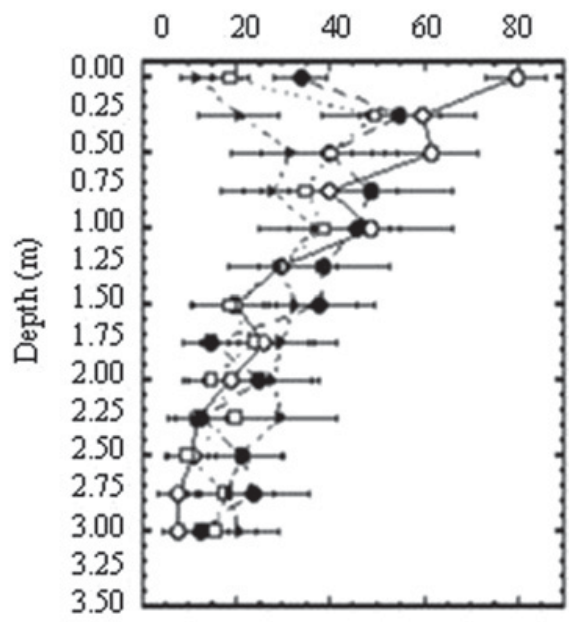

Fig. 4. Comparison of C-PC content between the water sampler described in this study and Van Dorn bottle. The vertical profile of $\mathrm{C}-\mathrm{PC}$ as a marker of cyanobacterial abundance in El-Malah canal showing the diel vertical migration of cyanobacteria is based on samples collected using the water sampler (form A) described in this study (panel A) and a Van Dorn bottle (panel B). A series of samples was conducted in the morning at 09:00 (open circles), midday at 12:00 (closed circles), afternoon at 16:00 (open squares) and midnight at 24:00 (closed triangles). Mean values and standard error bars are of three replicates.

traditional samplers have been avoided in the various forms of devices described in this study. A comparison of the described approach in this study and the water pumping approach for sampling water and plankton from various depths, showed comparable results (data not shown) but the described approach avoids mechanical shearing of plankton that often occurs in the pumping approach. In addition, the described approach requires no power source because water moves due to hydrostatic pressure variations. In addition, the various forms of devices described in this study can be self assembled/constructed. The described approach has advantages in reducing standard deviation among replicate samples and thus showed less sampling errors. Application of the described approach in this study for large bodies of water, large lakes or inland seas, is possible and would require further future studies and descriptions of new designs based on the described approach development. Modifications of the described devices and construction of other forms based on the described approach in this study would be of interest to enable new insights into the aquatic ecosystems.

Acknowledgements. The author is grateful to the staff members of Egyptian Academy of Scientific Research and Technology for reviewing the technical parts of the devices described in this study. 


\section{References}

Ahn C.-Y., Joung S.-H., Park C.-S., Kim H.-S., Yoon B.-D. and Oh H.-M., 2008. Comparison of sampling and analytical methods for monitoring of cyanobacteria-dominated surface waters. Hydrobiologia, 596, 413-421.

Baker A.L., 1970. An inexpensive microsampler. Limnol. Oceanogr., 15, 158-160.

Batten S.D., Clark R., Flinkman J., Hays G., John E., John A.W.G., Jonas T., Lindley J.A., Stevens D.P. and Walne A., 2003. CPR sampling: the technical background, materials and methods, consistency and comparability. Prog. Oceanogr., 58, 193-215.

Benfield M.C., Davis C.S., Wiebe P.H., Gallager S.M., Lough R.G. and Copley N.J., 1996. Video Plankton Recorder estimates of copepod, pteropod and Larvacean distributions from a stratified region of Georges Bank with comparative measurements from a MOCNESS sampler. Deep-Sea Res. II, 43, 1925-1945.

Bennett A. and Bogorad L., 1973. Complementary chromatic adaptation in a filamentous blue-green-alga. J. Cell Biol., 58, 419-435.

Blakar I.A., 1979. A close-interval water sampler with minimal disturbance properties. Limnol. Oceanogr., 24, 983-988.

Boney A.D., 1989. Phytoplankton - 2nd edition, Hodder and Stroughton Limited, London.

Broenkow W.W., 1969. An interface sampler using springactuated syringes. Limnol. Oceanogr., 14, 288-291.

Burd B.J. and Thomson R.E., 1993. Flow volume calculations based on three-dimensional current and net orientation data. Deep-Sea Res. I, 40, 1141-1153.

Clarke W.D., 1964. The jet net, a new high-speed plankton sampler. J. Mar. Res., 22, 284-287.

Clasby R.C., Reeburgh W.S. and Alexander V., 1972. A close interval syringe sampler. Limnol. Oceanogr., 17, 632-633.

Culberson C. and Pytkowicz R.M., 1970. A near-bottom water sampler. Limnol. Oceanogr., 15, 160-162.

Davis C.S., Gallager S.M. and Solow A.R., 1992a. Microaggregations of oceanic plankton observed by towed video microscopy. Science, 257, 230-232.

Davis C.S., Gallager S.M., Berman M.S., Haury L.R. and Strickler J.R., 1992b. The video plankton recorder (VPR): design and initial results. Arch. Hydrobiol. Beih. Ergebn. Limnol., 36, 67-81.

Davis C.S., Gallager S.M., Marra M. and Stewart W.K., 1996. Rapid visualization of plankton abundance and taxonomic composition using the Video Plankton Recorder. Deep-Sea Res. II, 43, 1947-1970.

Donaghay P.L., Rines H.M. and Sieburth J.M., 1992. Simultaneous sampling of fine scale biological, chemical and physical structure in stratified waters. Arch. Hydrobiol. Beih. Ergebn. Limnol., 36, 97-108.

Finucane J.H. and May B.Z., 1961. Modified Van Dorn water sampler. Limnol. Oceanogr., 6, 85-87.

Gleason G.R. and Goff G.F., 1963. A multi-level water sampler. Prog. Fish Cult., 25, 104-105.

Hays G.C., 1994. Mesh selection and filtration efficiency of the Continuous Plankton Recorder. J. Plankton Res., 16, 403-412.
Heaney S.I., 1974. A pneumatically-operated water sampler for close intervals of depth. Freshwater Biol., 4, 103-106.

Hernroth L., 1987. Sampling and filtration efficiency of two commonly used plankton nets. A comparative study of the Nansen net and the Unesco WP 2 net. J. Plankton Res., 9, 719-728.

Heron A.C., 1982. A vertical free fall plankton net with no mouth obstructions. Limnol. Oceanogr., 27, 380-383.

Holden M., 1976. Chlorophylls. In: Chemistry and biochemistry of plant pigments, 2nd edition, Goodwin T.W. (ed.), Academic Press, London, Vol. 2, 1-37.

Hopkins T.L., 1963. The variation in the catch of plankton nets in a system of estuaries. J. Mar. Res., 21, 39-47.

Joeris L.S., 1964. A horizontal sampler for collection of water samples near the bottom. Limnol. Oceanogr., 9, 595-598.

John E.H., Batten S.D., Stevens D., Walne A.W., Jonas T. and Hays G.C., 2002. Continuous plankton records stand the test of time: evaluation of flow rates, clogging and the continuity of the CPR time series. J. Plankton Res., 24, 941-946.

Kils U., 1992. The ecoSCOPE and dynIMAGE: Microscale tools for in situ studies of predator-prey interactions. Arch. Hydrobiol. Beih. Ergebn. Limnol., 36, 83-96.

Kimmerer W.J., 1984. A further improvement in the operation of opening/closing nets. J. Plankton Res., 6, 527-529.

Longhurst A.R., Reith A.D., Bower R.E. and Seibert D.L.R., 1966. A new system for the collection of multiple serial plankton samples. Deep-Sea Res. Oceanograph. abstr., 13, 213-222.

Lund J.W.G., 1954. The seasonal cycle of the plankton diatom Melosira italica (Her.) Kütz subsp. subarctica O. Müll. J. Ecol., 42, 151-179.

Lund J.W.G. and Talling J.F., 1957. Botanical limnological methods with special reference to the algae. Bot. Rev., 23, 489-583.

Mackas D.L., Denman K.L. and Abbott M.R., 1985. Plankton patchiness: biology in the physical vernacular. Bull. Mar. Sci., 37, 652-674.

Nicholls K.H., 1979. A simple tubular phytoplankton sampler for vertical profiling in lakes. Freshwater Biol., 9, 85-89.

O'Hara F.C., 1984. Description of a new automatic plankton sampler that collects and preserves multiple samples over a period of several days. Hydrobiologia, 111, 103-105.

Pierce E.L., 1937. A plankton collector for fast towing. Nature, 140, 1014-1015.

Sarada R., Pillai M.G. and Ravishanker G.A., 1999. Phycocyanin from Spirulina sp: Influence of processing of biomass on phycocyanin yield, analysis of efficacy of extraction methods and stability studies on phycocyanin. Proc. Biochem., 34, 795-801.

Sauter E.J., Schlüter M., Wegner J. and Labahn E., 2005. A routine device for high resolution bottom water sampling. J. Sea Res., 54, 204-210.

Schulze P.C., Strickler J.R., Bergstrom B.I., Berman M.S., Donaghay P., Gallager S., Haney J.F., Hargreaves B.R., Kils U., Paffenhiifer G.A., Richman S., Vanderpleog H.A., Welsch W., Wethey D. and Yen J., 1992. Video systems for in situ studies of zooplankton. Arch. Hydrobiol. Beih. Ergebn. Limnol., 36, 1-21.

Seuront L. and Menu D., 2006. A pneumatically-operated, submersible, three-dimensional water sampler for microscale studies. Limnol. Oceanogr. Methods, 4, 260-267. 
Seymour J.R., Mitchell J.G., Pearson L. and Waters R.L., 2000. Heterogeneity in bacterioplankton abundance from 4.5 millimeter resolution sampling. Aquat. Microb. Ecol., 22, 143-153.

Slack H.D., 1955. A quantitative plankton net for horizontal sampling. Hydrobiologia, 7, 264-268.

Summerfelt R.C. and Lewis W.M., 1968. A water sampler employing a solenoid tripping mechanism. Trans. Am. Fish. Soc., 97, 287-289.

Sutherland T.F., Leonard C. and Taylor F.J.R., 1992. A segmented pipe sampler for integrated profiling of the upper water column. J. Plankton Res., 14, 915-923.
Tuel M.D. and Knauer G.A., 1982. Improvement of the predeployment net closure procedure used with opening/closing plankton nets. J. Plankton Res., 4, 973-975.

Van Dorn W.G., 1957. Large-volume water sampler. Trans. Am. Geophys. Union, 37, 682-684.

Walker C.R., 1955. A modification of the Kemmerer water bottle for sampling shallow waters. Prog. Fish Cult., 17, 41.

Warner A.J. and Hays G.C., 1994. Sampling by the Continuous Plankton Recorder survey. Prog. Oceanogr., 34, 237-256.

Wiebe P.H. and Benfield M.C., 2003. From the Hensen net toward four-dimensional biological oceanography. Prog. Oceanogr., 56, 7-136. 